local authorities, and he, too, insisted that the new National Lending Library for Science and Technology would not dispense with the need for technical libraries in the municipal and county library systems.

In a stimulating paper of some general interest, Dr. J. Trenaman, lisison officer for further education, British Broadcasting Corporation, under the title "Libraries as a Social Force", described a survey of opinion towards broad educational ends, from which he concluded that about 55 per cent of those in the sample were at least receptive to new and even unwelcome ideas, while the remaining 45 per cent were resistant, at least to the extent of avoiding unaccustomed ideas or not being interested. This resistant sector had usually received only an elementary early education, whereas those who were interested in education had had a fairly good early education, about half having been to a secondary school. They were interested in the more serious radio and television programmes and were also members of a library. There was an upper level of 25 per cent of the whole sample who had mostly received a grammar school education, with a keen interest in further learning and who would be the more serious readers in the libraries. Dr. Trenaman believes that the machinery of education as a whole operates selectively, and accordingly the chief responsibility for adult education rests upon the informal agencies, especially the public library service, the Press and the broadcasting authorities because they have an access denied to all other information agencies. He also emphasizes the profound and durable influence of our early education.

\title{
EFFECTS OF PLANT DECOMPOSITION PRODUCTS IN THE SOIL
}

\begin{abstract}
THE inhibitive effects, on the germination of seeds and on seedling growth, of products from decomposing plant materials in soil have been examined by Z. A. Patrick and L. W. Koch (Canad. $J$. Bot., 36, 621 ; 1958). Substances capable of inhibiting the respiration, germination and growth of tobacco seedlings were obtained after residues from timothy, corn, rye or tobacco plants had been allowed to decompose under appropriate conditions in the soil. Bio-assay tests, based on manometric methods, made it possible to determine some of the conditions under which the decomposition gave rise to phytotoxic by-products and to obtain rapidly an accurate measure of the degree of their toxicity.

Among the factors affecting the production of the toxic products, the species and stage of maturity of the plant material added, the water content and $p \mathrm{H}$ of the soil, and the length of the decomposition period, were the most important. Substances capable of reducing the respiration of tobacco seedlings by 50-90 per cent were consistently obtained when any of the plant residues examined had been decomposing for 15-25 days under conditions of high soil moisture and a $p H$ value of the soil solution below $5 \cdot 5$. Timothy yielded substances with the highest toxic activity, followed by corn, then rye, and finally, tobacco. Aqueous extracts of unamended soil or of macerated
\end{abstract}

tissues, prepared either before decomposition or when decomposition was inhibited by autoclaving, were not toxic. The toxic substances, obtained by water extraction, showed an inhibiting effect on respiration of tobacco seedlings after an exposure of less than one hour and also induced darkening and necrosis of root cells. Some extracts affected the cells of the apical meristem most severely while others affected only the cells of the elongation region.

The toxic substances have not yet been identified, but they were relatively non-specific in their action, affecting several test plants in approximately the same manner. Many of them possessed antifungal activity. They were soluble in water, insoluble in petroleum ether, stable in acid, and most active in the $p$ H range $4 \cdot 5-5 \cdot 8$. They were precipitated by alkali and their activity was markedly reduced when they were readjusted to the acid-range. They were also stable to heat and did not lose their activity in storage at $1-3^{\circ} \mathrm{C}$. provided they were covered by a layer of toluene. Because of their rapid production and their marked injurious effects on various plants, the authors consider that these toxins may be important under field conditions as the primary factor in some root rots and in predisposing plants to attack by organisms not normally regarded as being pathogenic.

\section{THE NATIONAL INSTITUTE OF AGRICULTURAL BOTANY}

\begin{abstract}
7 HE report for 1957 of the National Institute of Agricultural Botany has recently been published*. The Trials Branch of the Institute has, as usual, carried out an extensive programme of work and the performance of a large number of varieties of the main agricultural and horticultural crops has been assessed. A very special requirement of sugar beet varieties is resistance to bolting, and the results are given of a special series of early-sown sugar beet trials designed to test resistance to premature flowering. The now variety from the Cambridge

- National Institute of Agricultural Botany. Thirty-eighth Report and Accounts, 1957. Pp. 56. (Cambridge: National Institute of Agricultural Botany, 1958.)
\end{abstract}

Plant Breeding Institute, known as Cambro, gave less than 1 per cent of bolters compered with commercial varieties where the percentage varied from 5 to 20 . The potato trials have included for the first time a number of foreign varieties from the Continent and North America. The work of the Seed Production Branch has continued to expand, and as well as administering the various field approval and seed certification schemes the Branch has intensified its inquiries into problems of seed production.

The report covers the first full season of operation of the national scheme for the comprehensive certification of herbage seeds. In launching a scheme covering 25,000 acres in its first season, the 